\title{
Digital Marketing Training For UMKM Of Tarakan City
}

\author{
Erick Karunia $^{1 *}$, Ahmad Juliana ${ }^{2}$, Syahran ${ }^{3}$, Ahmatang ${ }^{4}$, Nurul Hidayat ${ }^{5}$, Budi \\ Hasyim $^{6}$, Muh. Irfandy Azis ${ }^{7}$,Shalahuddin 8 \\ 1,2,3,4,5,6,8 Management Study Program, Faculty of Economics, \\ University of Borneo Tarakan,Indonesia \\ ${ }^{7}$ Accounting Study Program, Faculty of Economics, \\ University Borneo Tarakan,Indonesia \\ * Corresponding Author: \\ Email: erickkarunia3@gmail.com
}

\begin{abstract}
ThisCommunity Service activity was carried out by a team of management and accounting lecturers of the Faculty of Economics, University of Borneo Tarakan on Digital Marketing Training for UMKM in the city of Tarakan. This training aims to provide knowledge about digital marketing to UMKM in the city of Tarakan which was held on Juny 28 to 11 july, 2021. The method used is the current approach with the participatory method of rural approach in the form of training and mentoring which is generally done through three stages; preparation, training and evaluation, so that it can be more easily understood by UMKM in the city of Tarakan. Participants in this training are representatives of several people with a number of 30 people who have a profession as UMKM actors in the city of Tarakan, and who are still relatively young on average also fall into the category of beginners. The result obtained is to increase knowledge for MSMEs in the city of the importance of Digital Marketing (DM) to increase sales and for the sustainability of the business carried out. This activity is expected to help UMKM actors in increasing revenue and also improving the knowledge in the digital era so as not to be crushed by the changing times.
\end{abstract}

Keywords: Digital Marketing, UMKM

\section{INTRODUCTION}

A country's economy is influenced by many factors, one of the factors that is an important part of a country's economy is the performance of Micro, Small and Medium Enterprises (UMKM). The UMKM sector can encourage job growth and advance the country's economic system. The performance of UMKM also plays an important role in strengthening and enhancing the country's development (Eniola and Ektebang, 2014).Through great challenges, UMKM and businesses have developed over the last two decades, so it is necessary for UMKM to create a competitive advantage (Kraja and Osmani, 2013). The competitive advantage that can be created by UMKM will not be separated from the use of technology.The development of 
digital technology has increased rapidly and most of them are implemented quickly to gain a competitive advantage (Kannan, 2017). UMKM must be able to adapt to various technologies, because in this decade changes in internet use are increasing rapidly, especially during a pandemic like today.

Communication methods and marketing strategies are now slowly starting to shift to digital systems that were previously done traditionally. Currently the use of digital technology has been carried out to communicate, even the integration of digital technology has been commonly done in everyday life (Ryan, 2016). Marketing activities that utilize technology resources are often referred to as digital marketing. Digital is the use of the internet and the use of other interactive technologies to create and connect dialogues between companies and consumers who have implemented them (Coviello, Milley and Marcolin, 2001). Marketing has changed the way businesses and other organizations communicate with consumers (Chaffey and EllisChadwick, 2019).With current technological developments, UMKM actors can take advantage of various digital media as a means and efforts to increase it to the hands of consumers and consumers can also recognize the products produced by these MSMEs easily and indirectly.

Digital channels in marketing have become an important part of the strategy of many companies. This can be used to market the company's products or services very cheaply and efficiently (Yasmin, Tasneem and Fatema, 2015). The use of digital marketing will also have an impact on company performance (De Pelsmacker, Van Tilburg and Holthof, 2018; Mutoni, 2018; Kimathi, Mukulu and Odhiambo, 2019; Islami, Wahyuni and Tiara, 2020; Djakasaputra et al., 2021).In the business world, there are also many who know and invest in online marketing when compared to offline chanel and not only because of the increasing number of internet users but also because this online marketing system allows for business people or UMKM to reach their sales and audience targets appropriately, effectively and efficiently when compared to traditional offline chanel such as newspapers,Billboards and radios. Moreover, digital marketing has a very measurable nature or often called highly measureable.

This means that someone who understands digital marketers can know well the set of digital marketers.Social media for now is still often used in digital marketing such as Facebook, Instagram, and Youtube. Facebook has features that make it easier for business people to create their business profiles as well as instagram but for promotional media they can also do through youtube channel media so that all can run and form a very wide reach.As for the partners in this activity are micro, small and medium enterprises (UMKM) they are representatives of several people who have 
professions as UMKM in the city of Tarakan, which is still relatively young on average also included in the category of beginners. However, in marketing activities still adhere to the traditional pattern. Melihal about this msme palaku need to be given training and introduction to digital marketing or also called Digital Marketing so that their marketing patterns are better and more effective and efficient and have a very wide reach.

\section{METHODS}

The implementation of activities is carried out using the rural approach parsitipatori method in the form of training and mentoring. Generally, it is carried out in several stages:

\section{Preparatory Stage}

At this stage of preparation that is done is the observation of UMKM that are considered stak on sales (quiet visitors). Next, interview sessions related to the sales strategies they use, and what training they have done in increasing the number of sales.

\section{Training Stage}

At this training stage, the material needed by the Faculty Economic is Digital Marketing Training which is held for two days, namely on July 10-11, 2021 with the following materials:

a.Introduction to Business Strategy

b.Introduction to Digital Marketing

c.E-Commerce Concept in facing competition

d.Digital Marketing Strategy

e.Discussion of the problems faced by business people / UMKM actors

\section{Monitoring and Evaluation Stage}

In this monitoring and evaluation stage is the final stage in the activity process, namely by looking at the level of understanding of participants when participating in training and benefits and follow-up after following this training activity process.

\section{RESULT AND DISCUSSION}

The results that have been achieved in this Community Service Program with the title of Digital Marketing Training for UMKM in Tarakan city have been implemented by a team of Lecturers in the Department of Management, Faculty of Economics, University of Borneo Tarakan. Form the results of the report as follows: 
1. Lecturer team meeting in order to prepare the agenda of activities and willingness of speakers on Monday, June 28, 2021 at 09.00 to 11.30 WITA. At this meeting has been determined by speakers in digital marketing training activities, namely Mr. Nurul Hidayat, S.E., M.Sc., Ph.D and Budi Hasyim, S.E., M.Sc.

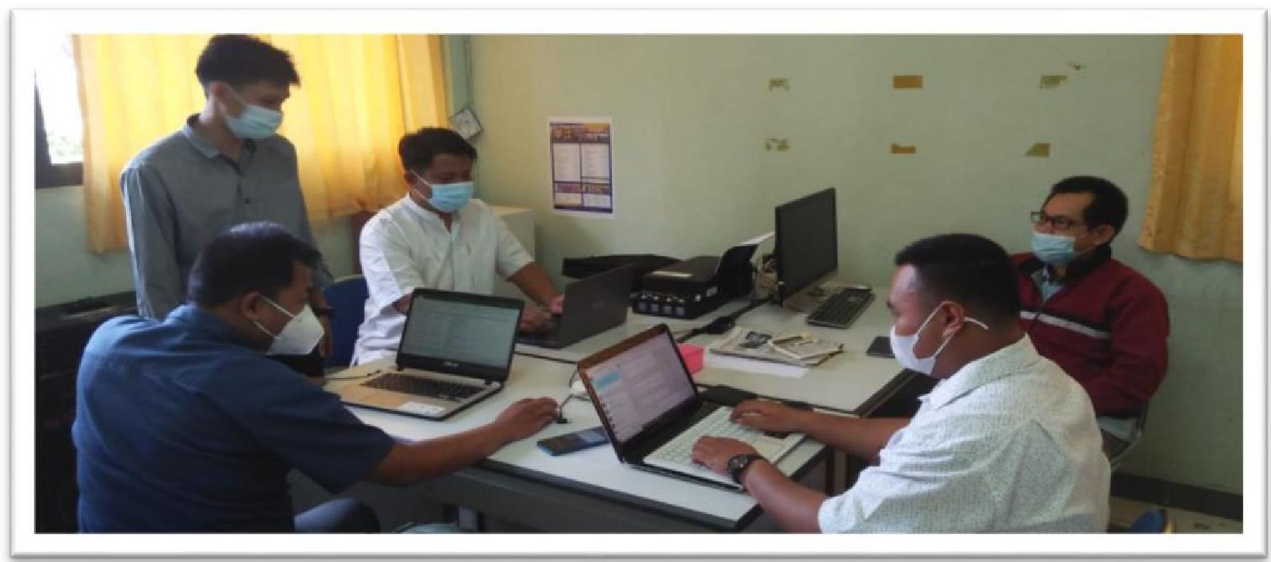

Fig 1. Meeting of Lecturer Team Preparing activities

2. Coordinating and recording service partners, namely UMKM actors, on Thursday, July 1, 2021 in determining the schedule of places and materials provided. The outcome of the agreement is determined on the 10th of sd. July 11, 2021 at the University of Borneo's economic faculty meeting held a maximum of 15 participants and continued to run health protocols.

3. Preparation for the implementation of training on July 5- 6, 2021 in the form of materials and speakers, prokes equipment (Mask and Hand Sanitizer) order consumption, absence, back drop and equipment that supports the activity.

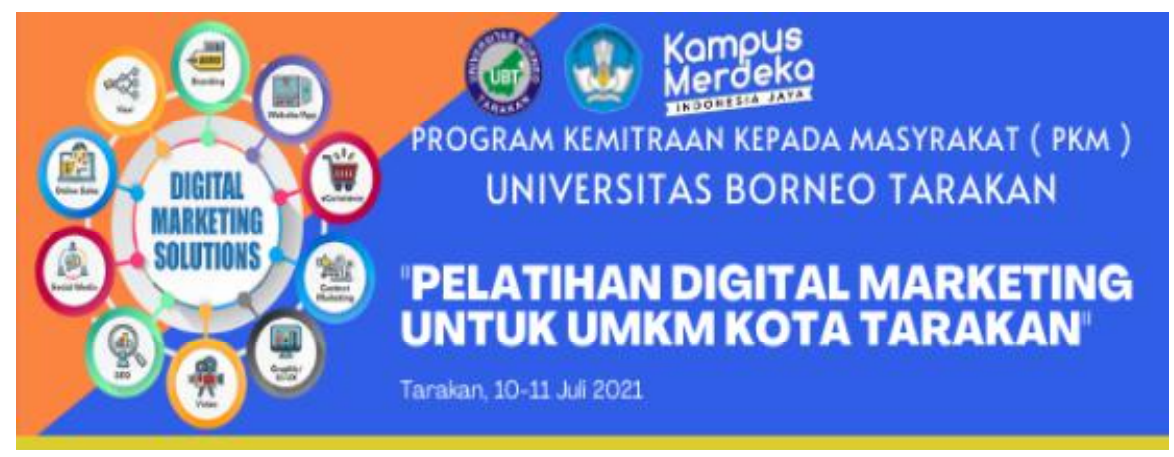

Fig 2. Back drop activities

https://ijcsnet.id 
4. The implementation of the phase 1 training on Saturday, July 10, 2021 at 09:30-finished at the meeting building of the faculty of economics guided by $\mathrm{Mr}$. Ahmatang, S.E., M.M and opened directly by the deputy Dean $1 \mathrm{Mr}$. Ahmad Juliana, $\mathrm{Ph} . \mathrm{D}$. and the chairman of the team implementing community service activities Mr. Erick Karunia, S.E., M.M as well as the delivery of preliminary materials by Mr. Nurul Hidayat, S.E., M.Sc., Ph.D. material delivered, namely: Introduction to Business Strategy, Introduction to Digital Marketing after that opened a discussion room for participants accompanied by Mr. Muh.Irfandy Azis, S.E., M.Acc., Ak., CA

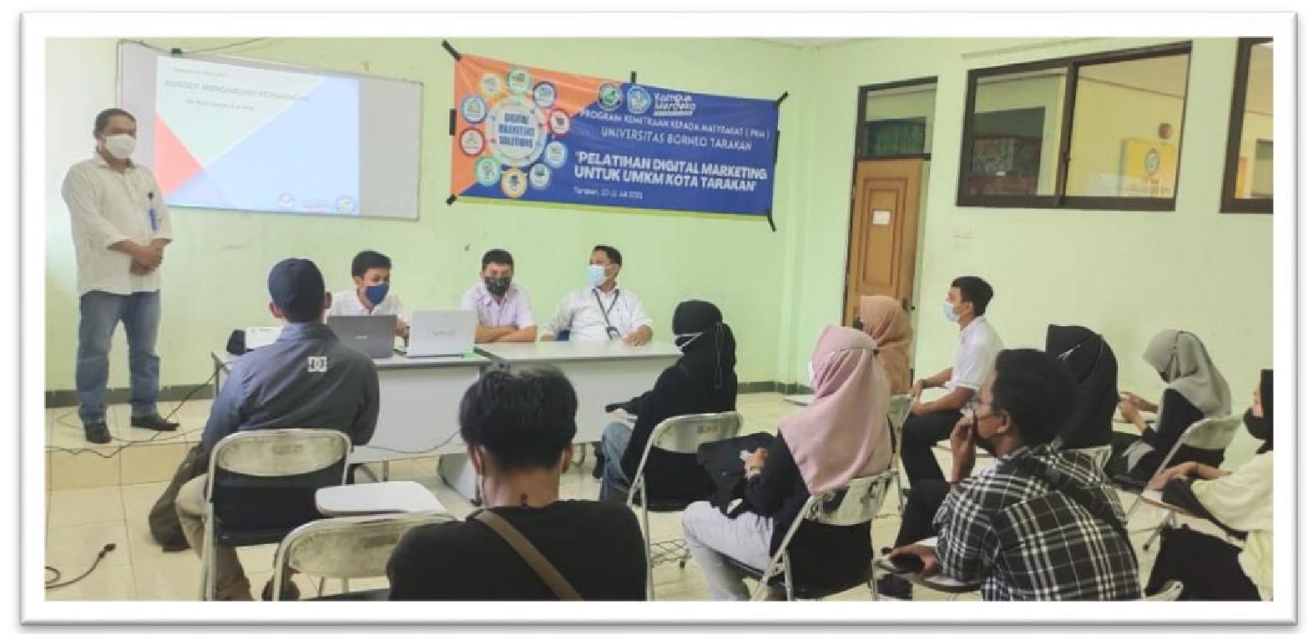

Fig 3. Opening and welcome of Training by the Chairman of PKM

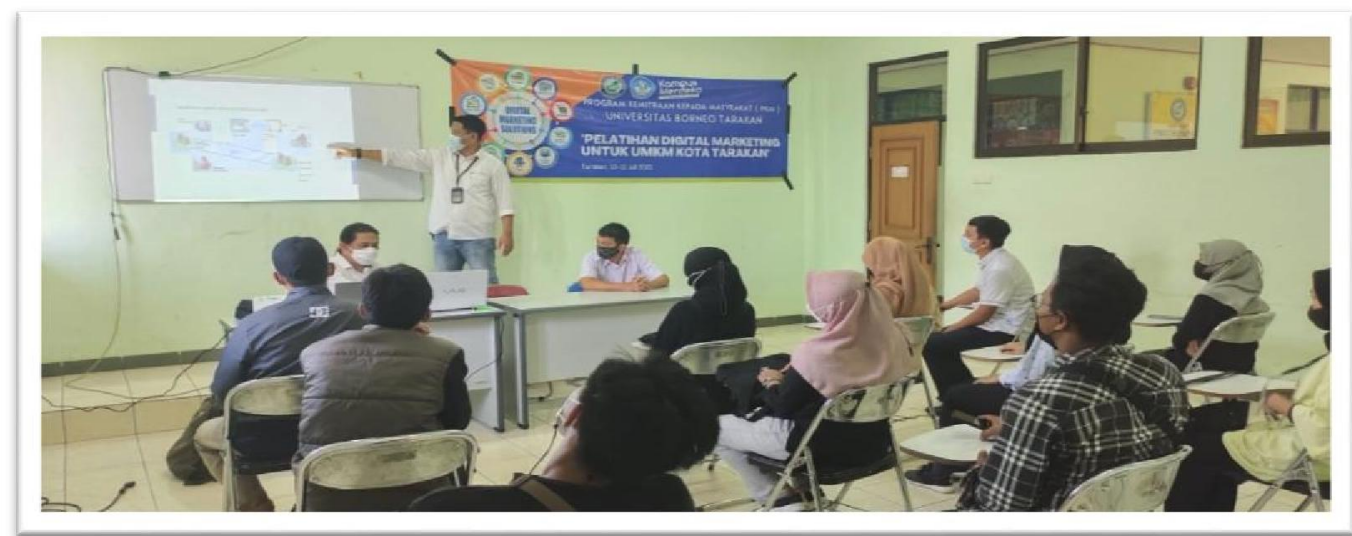

Fig 4. Submission of material by Mr. Nurul Hidayat, Ph.D. 
5. Continued the phase 2 training which was held on Sunday, July 11, 2021 at 10:00 am-finished, which was guided directly by the chairman of the implementation of digital marketing training activities for UMKM of the city tarakan Mr. Erick Karunia, SE., M.M with speaker Mr. Budi Hasyim, S.E., M.Sc with the material delivered, namely; The concept of E-Commerce in the face of competition and Digital Marketing Strategies. In the 2nd stage, there will be a trial practice of the use of media in carrying out business strategies, participants accompanied by speakers and $\mathrm{Mr}$. Muh.Irfandy Azis, S.E., M.Acc., Ak., CA.

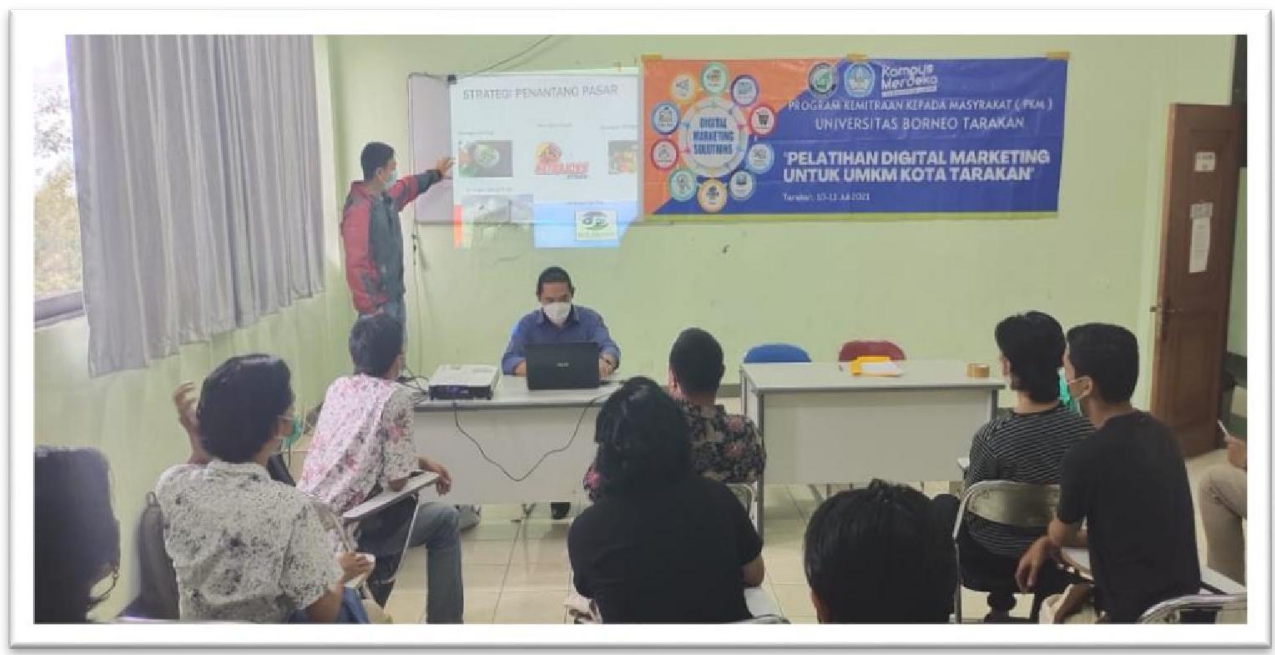

Fig 5. Training stage 2 by Mr. Budi Hasyim SE.,M.Sc

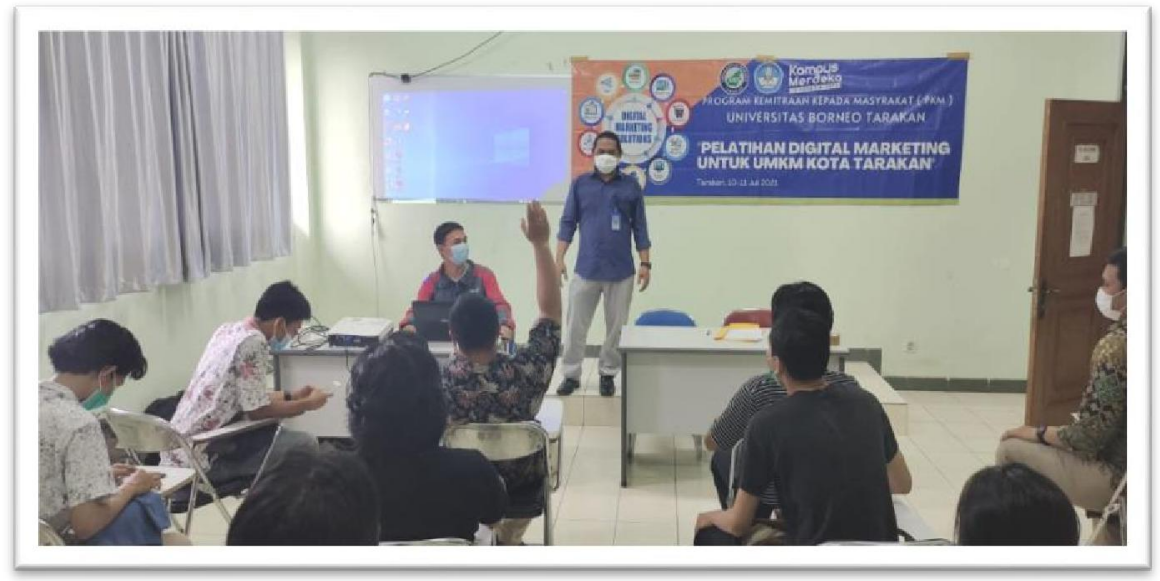

Fig 6. Discussion session 
International Journal Of Community Service

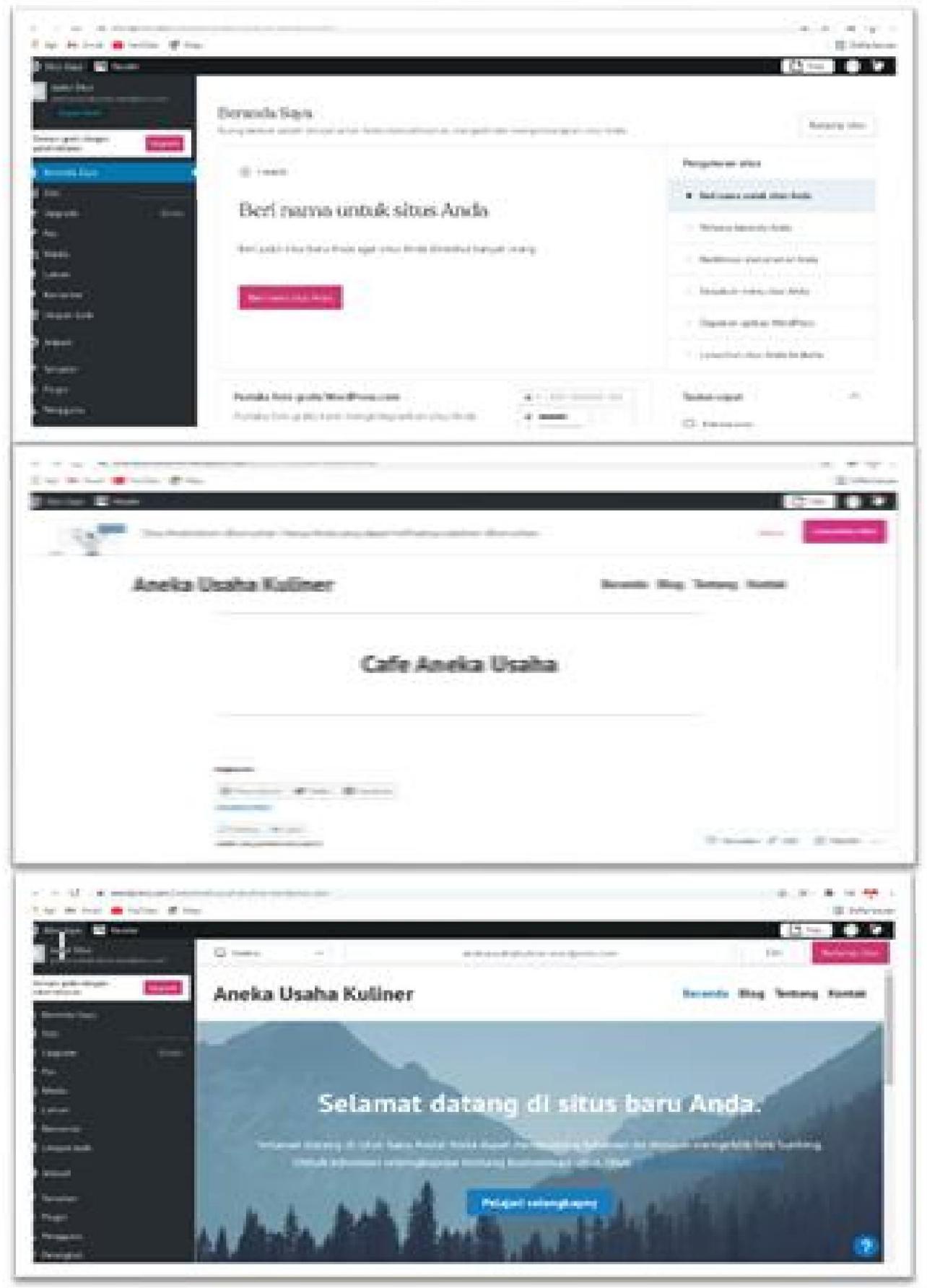

Fig 7. WordPress Online Site Creation Practices

https://ijcsnet.id 
International Journal Of Community Service

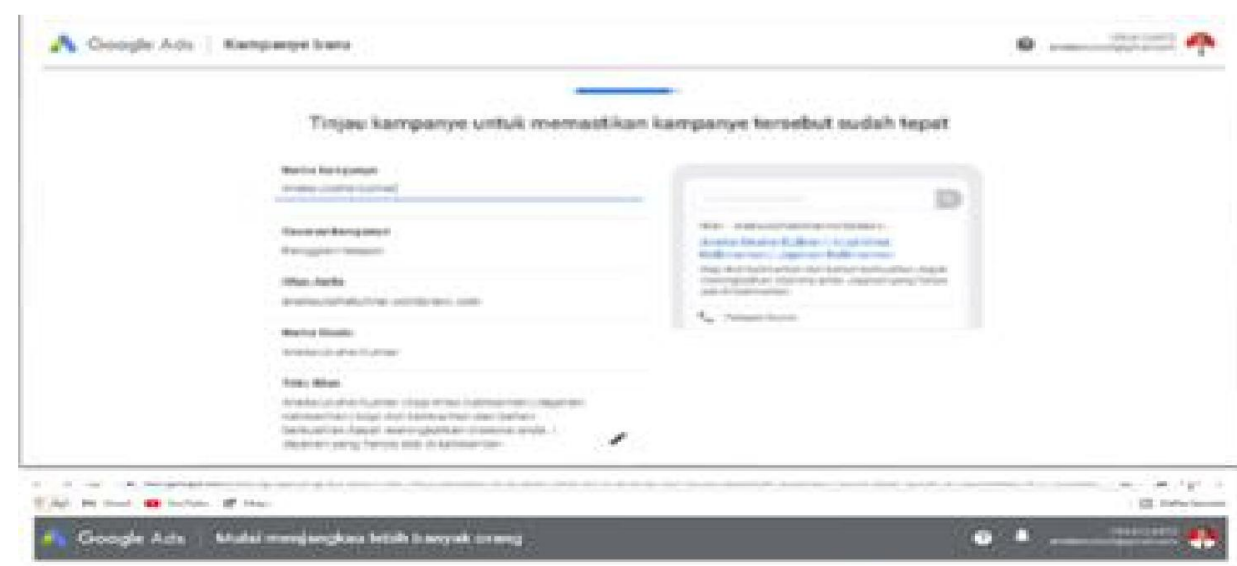

Seliamar anda bantuanil
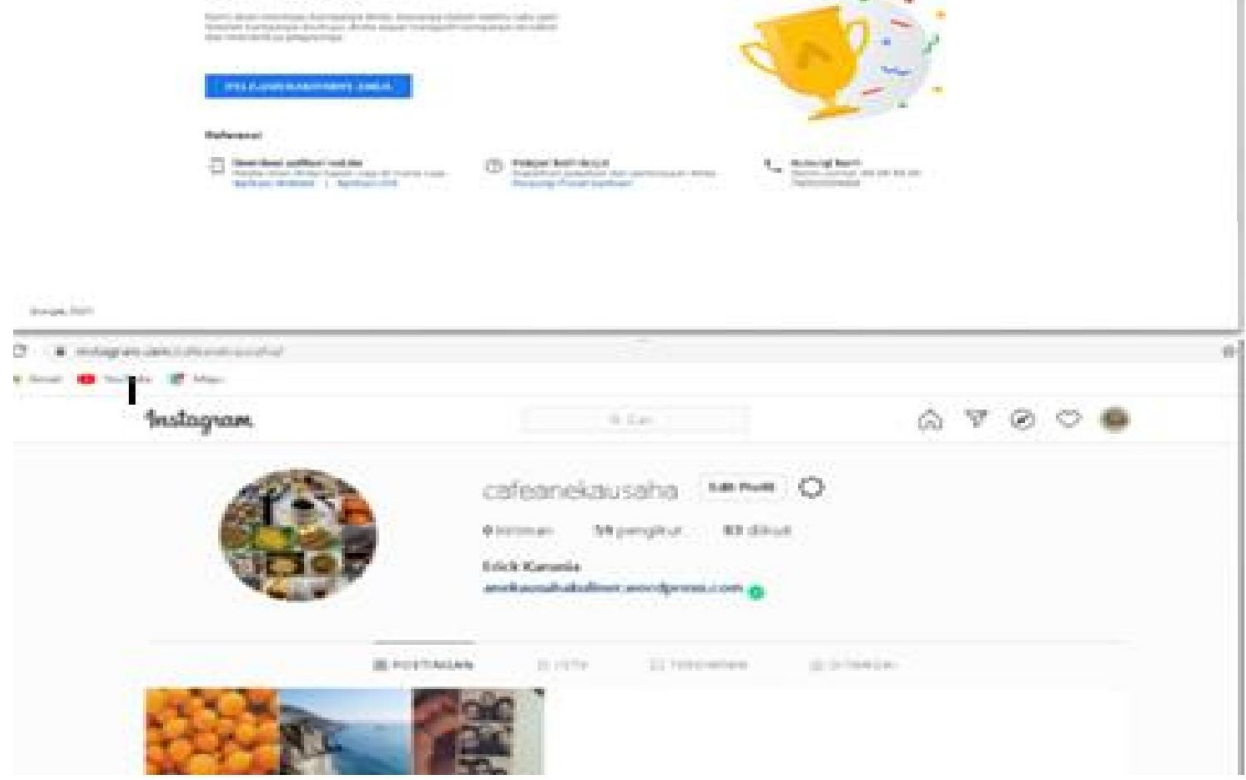

Fig 8. Instagram social media Business Account Creation Practices (IG) and Google Ads

6. In this training activity, monitoring and evaluation is carried out by distributing questionnaires to participants as post-activity respondents by asking several questions:

1. Is this training an activity that has never been done? The answers of all respondents said it was the first time it had been done. 
2. Is the material delivered in line with expectations? $90 \%$ of respondents said they were very much in line with expectations and 10\% said they were in line with expectations.

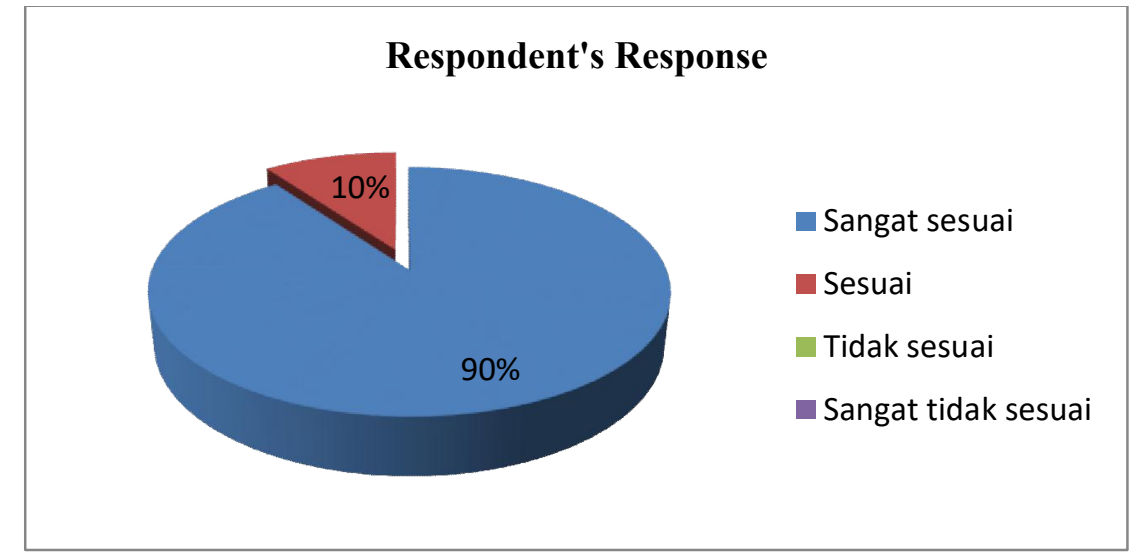

Fig 9. Respondent chart

3. Is the material provided easy to understand? $80 \%$ of respondents said it was easy to understand while $20 \%$ answered it was easy to understand. The participants were also given the opportunity to ask questions when there were difficulties in the material provided and participants also directly initiated the procedures for using online media accompanied directly by the speakers and the PKM team.

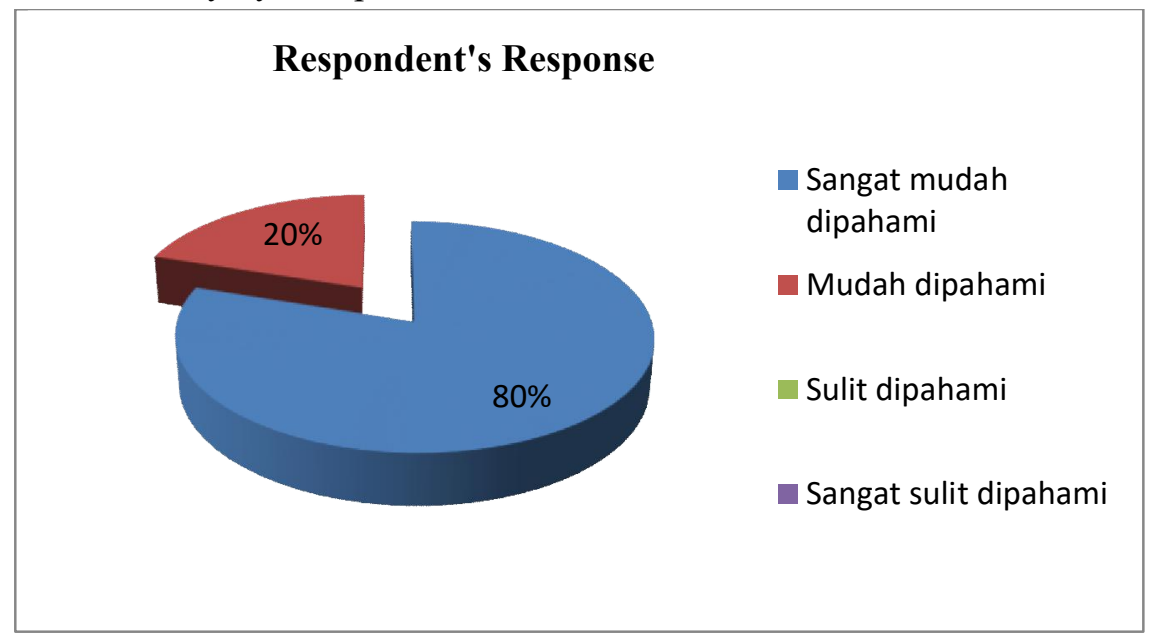

Fig 10. Respondent chart

4. How interested is in using digital marketing? 90\% said it was huge and $10 \%$ of respondents replied they had an interest in using digital marketing after this training. 


\section{Respondent's Response}

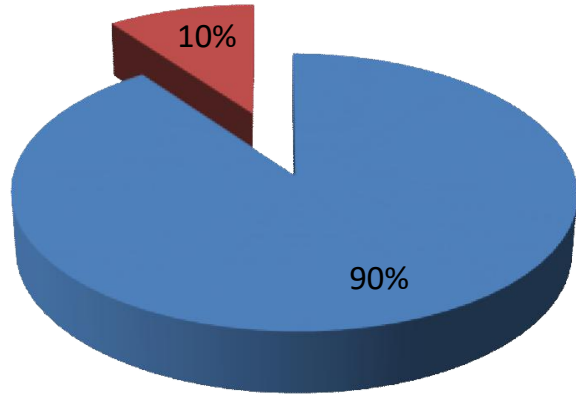

- Sangat besar

- Besar

Kecil

- Sangat Kecil

Fig 11. Respondent chart

5. Is the time for training sessions appropriate? $85 \%$ said it was appropriate and $15 \%$ were appropriate and $10 \%$ said it was not appropriate because it was too short to see enthusiastic participants who have the spirit and willingness to continue to explore knowledge about the importance of digital marketing.

\section{Respondent's Response}

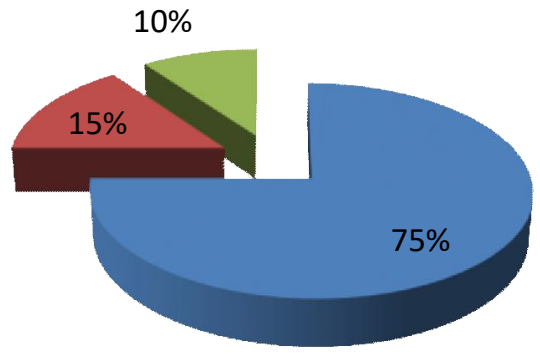

- Sangat sesuai

Sesuai

Tidak sesuai

Sangat tidak sesuai

Fig 12. Respondent chart

$\underline{\text { https://ijcsnet.id }}$ 
7. At the end of the session, a joint photo documentation session was conducted and thanked for the implementation of digital marketing training activities for msme tarakan city in the hope that the training that has been given can be useful in carrying out business strategies in order to increase sales interest.

\section{CONCLUSION}

Based on the results of activities and respondents' answer data, it can be concluded that in general, participants of the activity still lack understanding of digital marketing and the use of online marketing media.In the partnership program to the community with the title of digital marketing training for UMKM this tarakan city provides the following solution: By providing Digital Marketing training to UMKM business people, they will be able to feel the benefits and convenience in marketing the products they offer, as well as a solution in the problem of ignorance and lack of understanding in solving promotional strategies in the current era. In addition to being given an understanding and introduction to the use of Digital Marketing participants are also accompanied in the practice of creating accounts in digital media to add networking and expand marketing reach. Digital media accounts are taught in the form of wordpress Online Sites, Instagram Business (IG) accounts and Google Ads.

\section{ACKNOWLEDGMENTS}

The team of the implementation of community service activities thanked all pkm partners and all those involved in it as well as to the dean and vice dean of the faculty of economics of the University of Borneo for the advice and input that is very valuable so that this devotion can be carried out properly.

\section{REFERENCES}

[1] Chaffey, D. and Ellis-Chadwick, F. (2019) Digital marketing. Pearson uk.

[2] Coviello, N., Milley, R. and Marcolin, B. (2001) 'Understanding IT-enabled interactivity in contemporary marketing', Journal of interactive marketing, 15(4), pp. $18-33$.

[3] Djakasaputra, A. et al. (2021) 'Empirical study of Indonesian SMEs sales performance in digital era: The role of quality service and digital marketing', International Journal of Data and Network Science, 5(3), pp. 303-310.

[4] Eniola, A. A. and Ektebang, H. (2014) 'SME firms performance in Nigeria: Competitive advantage and its impact', International Journal of Research Studies in Management, 3(2), pp. 75-86.

[5] Islami, N. N., Wahyuni, S. and Tiara, T. (2020) 'The Effect of Digital Marketing on Organizational Performance Through Intellectual Capital and Perceived Quality in Micro, Small and Medium Enterprises', Jurnal Organisasi dan Manajemen, 16(1), 
pp. 59-70.

[6] Kannan, P. K. (2017) 'Digital marketing: A framework, review and research agenda', International Journal of Research in Marketing, 34(1), pp. 22-45.

[7] Kimathi, D. K., Mukulu, E. and Odhiambo, R. (2019) 'Effect of Digital Marketing on the Performance of MSMES in Kenya', Journal of Marketing and Communication, 2(1), pp. 1-23.

[8] Kraja, Y. and Osmani, E. (2013) 'Competitive advantage and its impact in small and medium enterprises (SMEs)(Case of Albania)', European Scientific Journal, 9(16).

[9] Mutoni, D. (2018) 'The effect of digital marketing on performance of commercial banks in Rwanda'. University of Rwanda.

[10] De Pelsmacker, P., Van Tilburg, S. and Holthof, C. (2018) 'Digital marketing strategies, online reviews and hotel performance', International Journal of Hospitality Management, 72, pp. 47-55.

[11] Ryan, D. (2016) Understanding digital marketing: marketing strategies for engaging the digital generation. Kogan Page Publishers.

[12] Yasmin, A., Tasneem, S. and Fatema, K. (2015) 'Effectiveness of digital marketing in the challenging age: An empirical study', International Journal of Management Science and Business Administration, 1(5), pp. 69-80. 